\title{
Hubungan Jenis Pekerjaan dengan Pemilihan KB Metode Kontrasepsi Jangka Panjang
}

\author{
Tri Yunita Fitria Damayanti', Dwi Kurnia Purnama Sari², Umu Qonitun ${ }^{3}$ \\ 1. STIKES Nahdlatul Ulama Tuban, email : maya@stikesnu.com \\ 2. STIKES Nahdlatul Ulama Tuban, email : dwikurnia@stikesnu.com \\ 3. STIKES Nahdlatul Ulama Tuban, email : umu@stikesnu.com
}

\begin{abstract}
Abstrak. Capaian Akseptor Metode Kontrasepsi Jangka Panjang (MKJP) sangat rendah dibandingkan dengan KB Non-MKJP. Penelitian ini membahas analisa hubungan jenis pekerjaan ibu dengan pemilihan KB metode kontrasepsi jangka panjang yang dipilih. Pendekatan cross sectional digunakan dalam penelitian ini. Populasi dan sampel dalam penelitian ini adalah Seluruh Akseptor yang menggunakan KB jangka panjang Di Dusun Kenthu, Desa Tahulu Kecamatan Merakurak, Kabupaten Tuban Bulan Juli-Agustus 2020. Variabel independen dalam penelitian ini adalah jenis pekerjaan ibu, sedangkan jenis kontrasepsi jangka panjang merupakan variabel dependen. Analisa data dengan menggunakan korelasi Spearman. Berdasarkan analisa hasil penelitian menunjukkan bahwa jenis pekerjaan tidak berhubungan dengan pemilihan KB Metode kontrasepsi jangka panjang. Jenis pekerjaan dapat dipastikan tidak berhubungan dengan pemilihan metode KB, maka untuk meningkatkan capaian program KB MKJP, pemerintah dapat melakukan penyuluhan tentang efek samping, indikasi, kontraindikasi, cara kerja semua alat kontrasepsi, dan komplikasi MKJP.
\end{abstract}

Kata kunci : MKJP, Keluarga berencana, Jenis Pekerjaan

\section{The Corellation between Type of Work and Selection of Long Acting Contraception Method In Kenthu Hamlet, Tahul Village, Merakurak District, Tuban Regency in 2020}

\begin{abstract}
The accomplishment of acceptors of long-term contraceptive methods is very low compared to longterm non-contraceptive methods. This study discusses the analysis of the relationship between the type of mother's occupation and the choice of long-term contraceptive method. A cross-sectional approach was used in this study. The population and sample in this study were all acceptors using long-term family planning in Kenthu Hamlet, Tulu Village, Merakurak District, Tuban Regency in July-August 2020. The independent variable in this study was the type of maternal occupation, while the type of long-term contraception was the dependent variable. Data analysis using the Spearman correlation. Based on the analysis of the research results, it shows that the type of work is not related to the choice of family planning methods of long-term contraception. The type of work can be ascertained that it is not related to the choice of family planning methods, so to improve the achievements of the long-term contraceptive method, the government can provide counseling about side effects, indications, contraindications, how all contraceptives work, and complications of the long-term contraceptive method.
\end{abstract}

Keywords: long-term contraceptive, family planning, type of work

\section{Pendahuluan}

Indonesia adalah negara ke 4 di dunia dengan estimasi jumlah penduduk terbanyak yaitu 256 juta jiwa (population reference bureau, 2015). Hasil estimasi penduduk tahun 2014 sebesar 252.124.458 jiwa yang terdiri atas 126.921.864 jiwa adalah penduduk laki-laki dan 125.202.594 jiwa penduduk perempuan, sedangkan jumlah PUS sekitar 34 juta pasangan. presentasi KB Aktif 60\% (Kemenkes, 2015). Berdasarkan fakta utama KB di Negara Indonesia tahun 2015, proporsi wanita usia subur yang tidak menggunakan KB masih sekitar $40 \%$ dan alasan utama wanita PUS tidak ber KB adalah tidak subur $(17 \%)$, masalah kesehatan (12\%), takut efek samping $(10 \%)$. Untuk hasil peserta KB Suntik sekitar $27,8 \%$, Pil 
$13,2 \%$, IUD $6,2 \%$, MOW $3,7 \%$, MOP 0,4\%, Kondom 0,9\%, Susuk 4,3\%, dan Metode MAL $0,1 \%$, dan sisanya merupakan peserta KB Tradisional meliputi 1,6\% menggunakan cara pantang berkala, 1,5\% Senggama terputus dan $0,5 \%$ dengan carai lain (BKKBN, 2015) Pola pemakaian kontrasepsi dimana metode kontrasepsi yang diminati akseptor antara lain suntik pada pilihan pertama, pil pilihan kedua, selanjutnya diikuti oleh IUD, MOW, MOP, Kondom, Implan, MAL dan metode kontrasepsi tradisional menjadi pilihan terakhir. Banyak faktor yang mempengaruhi salah satunya adalah Tingkat pengetahuan, Dukungan Keluarga, Sumber Informasi tentang Alat Kontrasepsi Jangka Panjang (BKKBN, 2015).

Seperti halnya yang terjadi di Kabupaten Tuban Kecamatan Merakurak, Khususnya Di Desa Tahulu Metode Kontrasespsi yang kurang diminati oleh masyarakat adalah Metode Kontrasepsi Jangka Panjang. Hasil data yang peneliti peroleh dari Puskesmas Merakurak tahun 2016 dimulai dari bulan januari sampai desember jumlah seluruh PUS di Desa Tahulu sekitar 806 Pasangan, PUS yang belum ber KB 247 Pasangan (30\%), PUS yang ber KB 559 Pasangan (70\%). Adapun macam KB yang digunakan yaitu KB Non MKJP sekitar (73\%). KB MKJP sekitar $(27 \%)$. Dari data diatas dapat disimpulkan bahwa capaian MKJP kumulatif sangat rendah dibandingkan dengan KB Non MKJP.

Kontrasepsi dalam keluarga berencana untuk mencegah kehamilan merupakan pilihan metode yang dianjurkan pemerintah. Kontrasepsi yang berkualitas diperlukan untuk memperoleh hasil yang baik, sehingga kesehatan sesksual dan kesehatan reproduksi meningkat baik bagi penggunanya. Faktor yang berperan untuk memilih penggunaan kontrasepsi meliputi paritas (jumlah anak yang telah dilahirkan)), pendidikan, jarak dengan kehamilan sebelumnya, biaya, usia, pekerjaan, jarak tempat tinggal ke tempat pelayanan kesehatan, serta dukungan keluarga atau suami (Herowati \& Sugiharto, 2019)

Peran penting Bidan sebagai fasilitator disepanjang bagi wanita sepanjang siklus hidupnya harus mengerti terhadap kebutuhan pasien dan memberikan informasi serta konseling yang menyeluruh mengenai semua jenis kontrasepsi terutama KB MKJP. Penelitian ini membahas analisa hubungan pekerjaan ibu dengan metode kontrasepsi jangka panjang yang dipilih.

\section{Metode}

Metode penelitian menggunakan cross sectional. Dalam penelitian ini populasinya adalah semua Akseptor KB MKJP Di Dusun Kenthu, Desa Tahulu Kecamatan Merakurak, Kabupaten Tuban Juli-Agustus 2020. Semua akseptor KB MKJP Di Dusun Kenthu, Desa Tahulu Kecamatan Merakurak, Kabupaten Tuban Bulan JuliAgustus 2020 menjadi sampel dalam penelitian ini adalah. Variabel independen penelitian ini adalah jenis pekerjaan ibu sedangkan variabel dependen dalam penelitian ini adalah jenis kontrasepsi jangka panjang. Untuk analisa data dalam penelitian ini menggunakan statistic nonparametris teknik analisis bivariat dengan menggunakan korelasi Spearman dengan skala data metode kontrasepsi jangka panjang menggunakan skala data ordinal menggambarkan tingkatan pilihan metode kontrasepsi jangka panjang yang efektif. Analisa data menggunakan SPSS. Untuk menyatakan bahwa terjadi hubungan yang bermakna pada sampel dapat diketahui dengan cara membandingakn $r$ hitung dengan nilai $r$ tabel untuk Spearman Rank Correlation. Batasan signifikan jika $p$ value $<0,05$.

Hasil Penelitian

1. Distribusi Pekerjaan Responden 
Tabel 1. Distribusi Pekerjaan Responden Di Dusun Kenthu Desa Tahulu Kecamatan Merakurak Kabupaten Tuban Pada Bulan Juli Sampai Dengan Agustus 2020

\begin{tabular}{llcc}
\hline No. & $\begin{array}{c}\text { Pekerjaan } \\
\text { Responden }\end{array}$ & $f$ & $\%$ \\
\hline 1. & IRT & 15 & 50 \\
2. & Tani & 9 & 30 \\
3. & Wiraswasta & 2 & 6.7 \\
4. & Guru & 4 & 13.3 \\
\hline & Jumlah & 30 & 100 \\
\hline
\end{tabular}

Berdasarkan tabel 1 diatas didapatkan dari 30 Responden yang diteliti setengahnya pekerjaan responden rata-rata adalah IRT yaitu sebanyak 15 orang $(50 \%)$.

2. Distribusi Pemilihan Metode Kontrasepi Jangka Panjang

Tabel 2. Distribusi Pemilihan Metode Kontrasepi Jangka Panjang Di Dusun Kenthu Desa Tahulu Kecamatan Merakurak Kabupaten Tuban Pada Bulan Juli Sampai Dengan Agustus 2020

\begin{tabular}{llcc}
\hline No. & \multicolumn{1}{c}{ MKJP } & F & $\%$ \\
\hline 1. & AKDR & 8 & 27 \\
2. & IMPLANT & 15 & 50 \\
3. & Metode & 3 & 10 \\
& Operasi Pria & & \\
& (MOP) & & \\
4. & Metode & 4 & 13 \\
& Operasi & & \\
& Wanita & & \\
& (MOW) & & 100 \\
\hline & Jumlah & 30 & \\
\hline
\end{tabular}

Berdasarkan tabel 2 diatas didapatkan dari 30 Responden yang diteliti sebagain besar menggunakan metode kontrasespi jangka panjang seperti Implant yaitu 15 orang $(50 \%)$.
3. Hasil analisa hubungan pekerjaan dengan pemilihan metode kontrasepsi jangka panjang

Tabel 3. Analisa hubungan pekerjaan dengan pemilihan metode kontrasepsi jangka panjang Di Dusun Kenthu Desa Tahulu Kecamatan Merakurak Kabupaten Tuban Pada Bulan Juli Sampai Dengan Agustus 2020

\begin{tabular}{|c|c|c|c|c|c|c|c|c|}
\hline \multirow{3}{*}{ Pekerjaan } & \multicolumn{8}{|c|}{ MKJP } \\
\hline & \multicolumn{2}{|c|}{ Implant } & \multicolumn{2}{|c|}{ AKDR } & \multicolumn{2}{|c|}{ MOW } & \multicolumn{2}{|c|}{ MOP } \\
\hline & $\mathrm{n}$ & $\%$ & $\mathbf{n}$ & $\%$ & $\mathrm{n}$ & $\%$ & $\mathrm{n}$ & $\%$ \\
\hline IRT & 5 & 16,7 & 6 & 20,0 & 4 & 13,3 & 0 & 0 \\
\hline Tani & 6 & 20,0 & 1 & 12,5 & 0 & 0 & 2 & 6,7 \\
\hline Guru & 3 & 20,0 & 0 & 0 & 0 & 0 & 1 & 3,3 \\
\hline Wiraswasta & 1 & 6,7 & 1 & 12,5 & 0 & 0 & 0 & 0 \\
\hline Total & 15 & 50 & 8 & 26,7 & 4 & 13,3 & 3 & 10 \\
\hline$p=0,547$ & & & & & & & & \\
\hline
\end{tabular}

Analisa data dengan bantuan SPSS menggunakan uji statistik Spearman menunjukkan $p$ value $=0,547$, karena batas signifikan terdapat hubngan antar variabel adalah nilai $\mathrm{p}<0,05$, maka jika nilai $\mathrm{p}>$ 0,05 dapat diartikan hasil analisa data menunjukkan jenis pekerjaan ibu tidak berhubungan dengan pemilihan metode kontrasepsi, khususnya metode kontrasepsi jangka panjang dalam penelitian ini.

\section{Pembahasan}

Pekerjaan merupakan kegiatan ekonomi seseorang dalam mencari nafkah pencaharian untuk memperoleh dan membantu pendapatan atau keuntungan. Status pekerjaan istri mungkin bisa berpengaruh terhadap pemakaian kontrasepsi. Terkadangm, Istri yang bekerja memiliki waktu yang lebih sedikit untuk mengurus anak dibandingkan dengan istri yang tidak bekerja, sehingga istri ysng bekerja lebih banyak menggunakan kontrasepsi dari pada istri yang tidak bekerja (Bainuan, 2015).

Penghasilan seseorang kemungkinan dapat menjadi alasan dalam pemilihan jenis kontrasepsi, faktor mahalnya alat kontrasepsi mempengaruhi akseptor 
memilih alat kontrasepsi dengan biaya murah dan pekerjaan akseptor KB menentukan penghasilan untuk memilih jenis alat kontrasepsi (Septianingrum et al., 2018). Metode kontrasepsi yang dipilih oleh akseptor juga dapat dipengaruhi oleh pengetahuan, pendapatan, usia, tingkat pendidikan, serta jumlah anak (Putri et al., 2019).

Berdasarkan hasil penelitian diatas menunjukkan bahwa tidak ada hubungan yang signifikan antara jenis pekerjaan dengan pemilihan jenis KB metode kontrasepsi jangka panjang. Penelitian sebelumnya melaporkan status pekerjaan sebagai pekerja atau tidak pekerja berhubungan dengan pemilihan metode kontrasepsi (Kadir, 2013), tetapi hasil penelitian ini menunjukkan jenis pekerjaan tidak mempengaruhi pemilihan metode kontrasepsi jangka panjang yang digunakan, hal tersebut dapat dikarenakan faktor lain pengetahuan yang kurang tentang metode kontrasepsi jangka panjang, pendidikan dan juga faktor motivasi dan dukungan dari keluarga (Bainuan, 2015). 15 akseptor hanya sebagai Ibu Rumah Tangga saja tanpa bekerja di luar rumah memakai metode MKJP Implant. AKDR dan MOW, sedangan 15 Akseptor KB terdiri dari 6 Tani, 4 Guru dan 2 Wiraswata tidak ada yang menggunakan MOW, tetapi memilih metode KB MKJP yang meliputi Implant, AKDR dan MOP.

MKJP dapat dipakai dalam jangka waktu lama (lebih dari 2 tahun), efektif dan efisiensi bertujuan untukn menjarangkan kelahiran lebih dari 3 tahun, mengakhiri kehamilan atau sudah tidak ingin hamil dan tidak menambah anak lagi (Siswanto \& Farich, 2015). Pasangan suami istri yang masih ingin memili anak karena anak masih sedikit cenderung untuk memilih untuk menggunakan kontrasepsi dengan efektifitas rendah, sedangkan pasangan yang sudah memiliki anak hidup banyak cenderung untuk menggunakan metode atau alat kontrasepsi dengan efektifitas tinggi (Triyanto \& Indriani, 2018)
Pasangan yang telah memiliki dua anak jenis kelamin laki-laki dan perempuan lebih memilih KB dengan Metode Kontrasepsi Jangka Panjang (Aryati et al., 2020), hal tersebut bisa menjadi faktor akseptor KB untuk memilih jenis metode kontrasepsi jangka panjang, walaupun Ibu bekerja jika belum memiliki lengkap jenis kelamin anak maka MKJP belum menjadi pilihan akseptor. MKJP sebagai salah satu upaya pemerintah untuk menekan pertambahan penduduk. Permasalahan pertumbuhan penduduk salah satunya Keluarga Berencana bagi Pasangan Usia Subur. KB dengan cara memakai kontrasepsi sebagai cara untuk merencanakan jumlah anak dan jarak kehamilan untuk kesejahteraan sosial ekonomi seluruh masyarakat melalui pengendalian dan perencanaan penduduk (Siswanto \& Farich, 2015).

Long Acting Contraceptive System atau dikenal dengan sebutan MKJP menjadi metode kontrasepsi yang tidak digunakan setiap hari dan tidak digunakan setiap akan melakukan hubugan suami istri. MKJP dibagi menjadi 2, MKJP non permanen meliputi IUD/AKDR dan Implan sedangkan MKJP permanen meliputi MOP dan MOW. MKJP tepat dan efektif untuk keluarga yang sudah tidak menginginkan anak lagi atau ingin membatasi serta menjarangkan kelahiran dalam waktu yang cukup lama sesuai dengan umur dan jumlah anak yang telah dimiliki (Boru, 2019), hal tersebut bisa menjadi faktor yang menjadikan jenis pekerjaan tidak berhubungan signifikan dengan pemilihan KB metode kontrasepsi jangka panjang.

$$
\text { MKJP memiliki banyak }
$$

keuntungan, efisien karena kontrasepsi MKJP jangka waktunya lama, efektif dan aman. Angka kegagalan KB MKJP lebih rendah dibandingkan dengan KB non MKJP. Angka kegagalan MKJP dilaporkan sejumlah 0,2 per 1000 akseptor KB, sedangkan metode non MKJP dilaporkan sejumlah lebih dari 10 per 1000 pengguna akseptor KB. Oleh karena itu metode 
MKJP bisa menjadi kontrasepsi yang lebih efektif untuk mencegah kehamilan (Boru, 2019).

Upaya pemerintah untuk meningkatkan pelayanan dan pencapaian program KB dapat dilaksanakan dengan penyuluhan tentang efek samping, indikasi, kontraindikasi, cara kerja semua alat kontrasepsi, dan komplikasi MKJP.

\section{Ucapan Terimakasih}

Penulis ngucapkan terimakasih terhadap semua yang telah berkontribusi untuk proses penelitian dan tempat penelitian.

\section{Daftar Pustaka}

Aningsih, B. S. D. \& Irawan, Y. L., 2019. Hubungan umur, tingkat pendidikan, pekerjaan dan paritas terhadap penggunaan metode kontrasepsi jangka panjang mkjp) di dusun iii desa pananjung kecamatan cangkuang kabupaten bandung. Jurnal Kebidanan, 8(1), pp. 33-40.

Aryati, S., Sukandi \& Widyastuti, D., 2019. Faktor-Faktor Yang Mempengaruhi Pemilihan Metode Kontrasepsi (Kasus Di Kecamatan Seberang Ulu I Kota Palembang). Majalah Geografi Indonesia, 33(1), pp. 79-85.

Bainuan, L. D., 2015. Tingkat pendidikan dan pekerjaan ibu dalam pemilihan kontrasepsi iud. Midwifery, pp. 25-30.

BKKBN, 2015. Perhitungan Alkon Program KКВPK. Jakarta: BKKBN.

Boru, Regina Elesley. (2019). MKJP Efisen dan aman.http://www.pusksmn.dinkes kotakupang.web.id/artikel/infokesehatan/item/94-mkjp-efisien-danaman.html

Herowati, D. \& Sugiharto, M., 2019. Hubungan antara kemampuan reproduksi, kepemilikan anak, tempat tinggal, pendidikan dan status bekerja pada wanita sudah menikah dengan pemakaian kontrasepsi hormonal di indonesia tahun 2017. Buletin
Penelitian Sistem Kesehatan, 22(2), pp. 91-98.

Kadir, A., 2013. Hubungan paritas dan pekerjaan akseptor dengan pemakaian kontrasepsi implant di bps kresna hawati kel. Karang jaya palembang tahun 2012. Jurnal Kesehatan, 1(11), pp. 109-114.

Putri, R. P., Sari, R. D. p. \& Ayu, P. R., 2019. Perbandingan Faktor-Faktor yang Mempengaruhi Penggunaan Kontrasepsi Intra Uterine Devices (IUD) dan Kontrasepsi Implant pada Wanita Usia Subur di Kecamatan Sukarame Kota Bandarlampung. Majority, 8(2), pp. 120-124.

Septianingrum, Y., Wardani, E. M. \& Kartini, Y., 2018. Faktor-faktor yang mempengaruhi tingginya akseptor $\mathrm{kb}$ suntik 3 bulan. Jurnal Ners dan Kebidanan, 5(1), pp. 15-19.

Siswanto, R. \& Farich, A., 2015. Faktor pemilihan metode kontrasepsi jangka panjang (mkjp) pada pasangan usia subur (pus) di wilayah kerja puskesmas segala mider kota bandar lampung. Jurnal Dunia Kesmas, 4(3), pp. 151-156.

Triyanto, L. \& Indriani, D., 2018. Faktor yang mempengaruhi penggunaan jenis metode faktor yang mempengaruhi penggunaan jenis metode subur di provinsi jawa timur. The Indonesian Journal of Public Health, 13(2), pp. 244-255. 